\title{
The Neuropsychiatric Syndrome of a Psychomotor Seizure Disorder in Shakespeare's Othello, The Moor of Venice
}

\author{
Alan J. Cohen, MD \\ University of California at San Francisco
}

Follow this and additional works at: https://jdc.jefferson.edu/jeffjpsychiatry

Part of the Psychiatry Commons

Let us know how access to this document benefits you

\section{Recommended Citation}

Cohen, MD, Alan J. (1986) "The Neuropsychiatric Syndrome of a Psychomotor Seizure Disorder in Shakespeare's Othello, The Moor of Venice," Jefferson Journal of Psychiatry. Vol. 4 : Iss. 1 , Article 8. DOI: https://doi.org/10.29046/JJP.004.1.005

Available at: https://jdc.jefferson.edu/jeffjpsychiatry/vol4/iss1/8

This Article is brought to you for free and open access by the Jefferson Digital Commons. The Jefferson Digital Commons is a service of Thomas Jefferson University's Center for Teaching and Learning (CTL). The Commons is a showcase for Jefferson books and journals, peer-reviewed scholarly publications, unique historical collections from the University archives, and teaching tools. The Jefferson Digital Commons allows researchers and interested readers anywhere in the world to learn about and keep up to date with Jefferson scholarship. This article has been accepted for inclusion in Jefferson Journal of Psychiatry by an authorized administrator of the Jefferson Digital Commons. For more information, please contact: JeffersonDigitalCommons@jefferson.edu. 


\title{
The Neuropsychiatric Syndrome of a Psychomotor Seizure Disorder in Shakespeare's Othello, The Moor of Venice
}

\author{
Alan J. Cohen, M.D.
}

Many of Shakespeare's characters suffer from the myriad of medical and surgical ailments that afflict mankind. Although many of these diseases serve merely to enhance the subtle shading of character in Shakespearean drama, certain disorders seem to provide a vital focus for the basic theme and plot development of the plays. No group of disorders is more implicated by the behavior and thought patterns of Shakespeare's characters than neuropsychiatric disease. Othello, the Moor of Venice stands out as a striking example of a tragedy in which the main character suffers grievous consequences from a disease that affects his behavior and thereby directs the course and outcome of the play.

In this essay, I will attempt to correlate the history, signs, and symptoms of Othello's disease with recognized neurological conditions, specifically partial psychomotor seizure disorders. I will cite many bits of evidence, although none are conclusive without a physical examination and diagnostic electroencephalogram. I will also make an argument in favor of Shakespeare's medical as well as literary expertise.

A brief synopsis of the plot will help set the stage for the clinical descriptions developed in this study. Othello, a general in the army of the Duke of Venice, has recently married a nobleman's daughter, Desdemona, against the wishes of her father. Iago, a soldier in the Moor's army, is angry with Othello for having chosen Cassio instead of himself to be first lieutenant. Iago plots to seek revenge both by discrediting Cassio and implicating Desdemona in an adulterous affair. Iago apparently has uncanny insight into Othello's psychological state; he seems to be able to predict the Moor's behavior and to sense the weaknesses in his suggestible nature. Thus, he toys with Othello's mind and exploits his credulity to achieve his own ends: the winning of Cassio's position and the destruction of Othello's newly-found marital happiness.

Early in the play, Othello defends his right to marry Desdemona in a revealing speech addressed to the Duke of Venice. Here he recounts among his heroic acts of war, "some distressful stroke/that my youth suffer'd (I.iii.157-58) (1). This is an early suggestion that Othello may have suffered a serious physical insult to the brain earlier in his life such as the acceleration-deceleration type

Dr. Cohen is a fourth-year resident at the University of California at San Francisco. 
head trauma that can cause temporal lobe scarring and injury. The petrous temporal bone is commonly involved in this type of injury, and many times such injuries result in subsequent seizure disorders.

Iago, revealing his intentions in the final scene of Act I, comments on Othello's gullibility: "The Moor is of a free and open nature,/ That thinks men honest that but seem to be so,/ And will as tenderly be led by th' nose/ As asses are" (I.iii.399-402). Patients with partial complex seizure disorder have been described as having a variability of temperament in which aggressiveness alternates with an "unctuous good-naturedness" (2). This aggression usually has an identifiable precipitant, triggered in many cases by a seemingly minor provocation. Persons with this condition may seem to harbor grudges, and then to give long-winded, circumlocutory explanations for their overactive behavior (2). As Iago had served under Othello for many years, he might be wellacquainted with the Moor's patterns of gullibility, violent aggression, and grudge-holding, which ultimately led him to ruin.

As Iago's plotting progressed, he framed Cassio as a trouble-maker and had him quickly dismissed as Othello's lieutenant. He accomplished this by convincing Othello that Cassio was guilty of starting a brawl in which another soldier was killed. Iago then remarked that Desdemona's "appetite (wishes) shall play the god/ With Othello's weak function (mental faculties)" (II.iii.347-48). As Iago plants the seeds of suspicion in Othello's mind about Desdemona's adultery, certain signs and symptoms of altered consciousness appear in the Moor's thought and behavior. A single conversation between Othello and Iago, cleverly manipulated by the scheming soldier, is enough to raise grave doubts in Othello's mind regarding his wife's fidelity. Desdemona appears directly after this conversation, and Othello greets her with "a pain upon my forehead, here" (III.iii.284). We see Othello as highly suggestible and easily swayed by Iago: "The Moor already changes with my poison:/ . . Not poppy, nor mandragora/ Nor all the drowsy syrups of the world/ Shall ever medicine thee to that sweet sleep/ Which thou ow'dst yesterday" (III.iii.325-332). Iago sensed Othello's disturbed thoughts, which were so agitated that the medicines of the time would not restore him to his former tranquility.

As Iago paints his portrait of guilt upon Cassio and Desdemona, Othello's violent nature quickly surfaces. "I'll tear her all to pieces," Othello cries (III.ii.431). Othello is now convinced; his grudge is immoveable. When Iago suggests that he may change his mind, Othello responds:

Never, Iago. Like to the Pontic Sea/ Whose icy current and compulsive course/ Nev'r feels retiring ebb, but keeps due on/ To the Propontic and the Hellespont,/ Even so my bloody thoughts, with violent pace,/ Shall nev'r look back, nev'r ebb to humble love,/ Till that a capable and wide revenge/Swallow them up. He kneels. Now by yond marble heaven,/ In the due reverence of a sacred vow/I here engage my words" (III.iii.453-462). 
This speech epitomizes the rash, violent, and implacable quality of Othello's personality; quite characteristic of the temporal lobe epileptic. In the next scene, Othello is seized with a "salt and sorry rheum," a distressing watering of the eyes (III.iv.51). This tearful change of emotion may be a sign of labile affect.

It is possible that his tearing of the eye is a device to provoke Desdemona to produce the handkerchief given to her by Othello (according to Iago's story, given away as a love offering to Cassio). This was the "ocular proof" Othello sought to verify Iago's story. In actuality, the handkerchief was accidently dropped by Desdemona after she offered it to Othello to soothe his headache (III.iii.287). Emilia, Desdemona's maidservant, found the handkerchief and gave it to her husband, Iago, who then placed it in Cassio's room to set the stage for Cassio's incrimination. As Othello questions Desdemona about the whereabouts of the handkerchief, he describes its history. He says it was given to his mother by an Egyption charmer, a mind reader, and it possesses magical properties of love: "To lose't or give't away were such perdition/ As nothing else could match" (III.iv.67-68). A "temporal lobe personality" has been described, notably a "deepening of emotional responsiveness characterized by religious fervor and cosmic concerns" (2). The question arises as to whether this condition pertains to Othello, who continues, "there's magic in the web of it./ A sibyl, that had numb'red in the world/ The sun to course two hundred compasses,/ In her prophetic fury sew'd the work; / The worms were hallowed that did breed the silk,/ And it was dy'd in mummy (fluid drawn from embalmed bodies) which the skillful/ Conserv'd of maiden's hearts"' (III.iv.70-75). Desdemona responds, "Why do you speak so startingly and rash?" (III.iv.79).

As Othello's suspicions mount, his nervous excitement increases. "Handkerchief-confessions-handkerchief! To confess, and be hang'd for this labor-first to be hang'd and then to confess. I tremble at it. Nature would not invest herself in such shadowing passion without some instruction. It is not words that shakes me thus. Pish! Noses, ears, and lips. Is't possible? Confess? Handkerchief? O devil! Falls in a trance" (IV.i.34-43). There follows then the exchange: Cassio: “What's the matter?” Iago: "My lord is fall'n into an epilepsy. This is his second fit; he had one yesterday." Cassio: "Rub him about the temples." Iago: "No forbear,/ The lethargy must have his quiet course;/ If not, he foams at mouth, and by and by/ Breaks out to savage madness." Here in this short sequence is a classic description of temporal lobe epilepsy, rich in clinical signs and symptoms. It is the first explicit account of Othello's epilepsy in the play, although Iago refers to a previous fit the day before. The phrase "shadowing passion" is glossed by the Riverside Shakespeare editor as "a coming over one like a shadow or filling the imagination with shapes and figures" (1288 n.40). This aura is typical of TLE (temporal lobe epilepsy) replete with visual symptoms (3). Disturbances of language are present: "Pish! Noses, ears and lips." "Confess? Handkerchief? O devil!" This shows less dysphasia (typical of dominant hemisphere foci) but more automatisms of speech. Consistent with the nondominant focal origin are the hallucinations of formed vision (facial parts) 
which are common in right-sided temporal lobe seizure foci. Othello might have suffered micropsia or macropsia of Iago's face, another feature of this disorder (2). Affective disturbances occur in $80 \%$ of patients with TLE, usually uneasiness, depression, or fear (2). This seems apparent in Othello's words, "I tremble at it" (IV.i.39). He also displays vertiginous symptoms as he falls to the ground. Iago warns Cassio of Othello's antisocial behavior ("savage madness") during fits; this is a hallmark of TLE (2). "Epileptic violence is not premeditated, is unprovoked and senseless, and the patient usually is amnestic of the episode" (2). Olfactory symptoms, from uncinate foci, are not specifically referred to here. However, Othello constantly refers to the sulfur pits of Hell: "Fire and brimstone!" (IV.i.234) and “deep dark-smelling chambers, bloody, bloody, bloody." The text, Medical Neurology (3) describes a hallucination characteristic of TLE as "burnt blood or bad eggs"; sulfurous brimstone.

Finally, Othello appears entirely amnestic for the epileptic episode. When asked whether he hurt his head, he responds, "Dost thou mock me?" (IV.i.60). If he had known of his fall, he would not have responded this way. Othello infers from the reference to his injured head that Iago's implication is that he is a “horned man" (IV.i.62), a cuckold husband. Thus in Othello's true "amnestic absence,"' he could only have assumed the reference to his head to be an implied mockery of his cuckoldry.

As Othello's passionate anger wells up, he can barely conceal it from Desdemona. He strikes her publicly without immediate provocation in the first scene of Act IV, causing a visitor from Venice, Lodovico, to say, "Are his wits safe? Is he not light of brain?” (IV.i.269). Othello's persistence in his delusions is apparent when he talks with Emilia about his wife's relationship to Cassio. Although defended by Emilia as an honest, pure, and chaste woman, Desdemona is still in Othello's mind from Iago's accusations, and he dismisses Emilia's defense completely: "She's a simple bawd/ That cannot say as much" (IV.ii.2021). This demonstrates the irrational, grudge-holding personality sometimes associated with TLE.

In V.ii, Othello prepares to strangle his wife. In his speech before the murder, allusions are made to odors, roses especially: "I'll smell thee on the tree./ O balmy breath" (V.i.15-16). Uncinate epileptic foci can manifest themselves with sweet as well as stench-like features. Desdemona awakens and says, "And yet fear you're fatal then/ When your eyes roll so" (V.i.36-37). This may represent nystagmus or vertigo. Desdemona goes on to ask, "Why gnaw you so your nether lip?” (V.i.43); while this is a common sign of anxiety, it is also a feature of epileptic seizures. Othello then kills Desdemona in a somewhat premeditated fashion.

The play Othello was based on a novella by Grialdi Cynthio, Shakespeare's contemporary. Cynthio's moral was that Desdemona made an unhappy choice in marrying a man so different from her in every way: race, creed, and education. Shakespeare emphasized the color difference, but firmly established Othello as a Christian, "and allows the original moral of the story to degenerate into an 
aspect of the partial or evil interpretations put upon the events by disaffected or incompetent observers" (1199). Here is an indication of Shakespeare's genius of invention, for how can the playwright change the plot, for his own purposes, and yet make the story believable? The Moor is certainly not of "weak mind"; he displays a gift of knowledge as well as courage in battle. By his portrayal as an epileptic, his suspiciousness, labile mood, violent aggression, and gullibility are all made more believable to the audience. Othello murders his wife on the second night in Cyprus, the location for most of the play. The rapidity of events would hardly allow time for a normal person's suspicions to take shape, much less find fruition in an act of murder. However, a person given to irrational thoughts and actions could conceivably act this quickly and violently. Shakespeare must have known the quality and impact upon tragedy that the device of an epileptic disorder would create.

This crime of passion would have been drawn out in lengthy schemes and twisted plots. Shakespeare chose to hang his case upon the flimsy threads of a

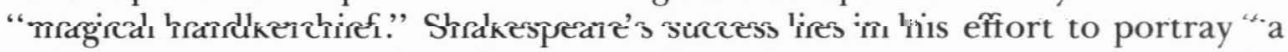
sober, plain representation of human reality. The truer that representation, the more it suggests conformity to ancient schemes and formulae exploring the human condition" (1).

There have been many books and articles written regarding Shakespeare's knowledge of medicine. Whether he had formal schooling in clinical medicine or merely experience of human conditions, is unknown. We do know, however, that his son-in-law, who lived in the same house as Shakespeare for many years, was a physician. Shakespeare knew many signs and symptoms of disease and their effects upon the life and behavior of man. This is one reason he was so successful as a dramatist; his plays were believable. His careful implementation of subtle human quirks and foibles, epilepsy in this case, makes his plays good entertainment.

\section{REFERENCES}

1. Shakespeare W: Othello, the Moor of Venice. In The Riverside Shakespeare. Edited by Evans, GB. Boston, Houghton Mifflin Co, 1974

2. The Harvard Guide to Modern Psychiatry. Edited by Nichols Jr, AJ. Boston, Belknap Press, 1978

3. Gilroy J, Meyer J: Medical Neurology. New York, MacMillan Co, 1979 